\title{
Critical Internal Factors Influencing The Centralization Of Stock Procurement Processes In A South African Municipality
}

Zwelihle Wiseman Nzuza, Durban University of Technology, South Africa Lawrence Mpele Lekhanya, Durban University of Technology, South Africa

\begin{abstract}
The purpose of this paper was threefold: 1) to examine the internal factors influencing centralization of stock procurement processes, 2) to assess the relationship between demographic factors and staff understanding of Information Communication Technology (ICT) with performance improvement, and 3) to examine the relationship between prevention of corruption with management commitment. A structured questionnaire was used to collect data from 82 members of staff from procurement division in a South African municipality, with specific reference from the KwaZulu-Natal (KZN) Province. A census sampling method was used and a Statistical Package for Social Scientists (SPSS) software was used to analyse the data. The results indicate that ICT, planning tools, communication tools, inbound logistics, and staff competency are the most contributing factors influencing decentralized procurement process of stocks in a South African municipality. Although a hypothesis between performance improvement and gender was rejected, the study showed significance relationships between performance improvement with qualification ( $p=.035)$, experience $(p=.000)$, and age $(p=.000)$. It further proved that there is a significance relationship between understanding the ICT and performance improvement $(p=.031)$ and that prevention of corruption is significantly related with management commitment ( $p=.001)$.

Based on the results, the study recommends that a supporting internal control should be established to ensure that the centralization of stocks by procurement is executed by individuals with clear understanding of inbound logistics, clear communication, commitment, and comprehensive planning. Since the findings of this study are based on 82 members of staff from one South African municipality, it is recommended that a larger sample size may be used in future studies in order to improve accuracy of the results.
\end{abstract}

Keywords: Centralized Procurement; Procurement Of Stocks; Information Communication Technology (ICT); Logistics; Staff Competency; Planning Tools; Communication Tools

\section{INTRODUCTION}

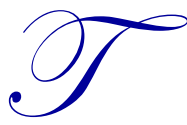

he concept of municipal procurement is the focal point of significant academic attention around the world. A municipal procurement can be defined as a process or function to acquire and receive stocks in the organization. This function should be effective in terms of preparing and processing the customer demands as well as the end receipt and approval of payments (Intaher \& Johanna, 2012). In 1995, because of the variety of issues in the South African municipalities, it was discovered that there is a need for a consistent legislative framework that will empower government's procurement reform policy objectives. A 10-Point (Interim Strategies) Plan was also adopted in November 1995 and its design was aimed to impact positively on the participation in the bidding system of small, medium and micro enterprises. Thereafter, a Green Paper on Public Sector Procurement Reform in South Africa was published in April 1997 with a purpose to uplift black economic empowerment for small and medium-sized business. In the same way, during November 2000 a new plan was formed and discussed by the Cabinet to suggest certain changes to the procurement system (Policy strategy to guide 
uniformity in procurement reform processes in government, 2003). In this regard, a Preferential Procurement Policy Framework Act (PPPFA) - act No. 5 of 2000 - was promulgated to achieve the best results on procurement practices. With reference to section 217 (1) of the PPPFA, the primary objective towards its promulgation was simply to ensure fairness, equity, transparency, competitiveness and cost effectiveness in the control of municipal inventories (Watermeyer, 2011). However, there are challenges that are still restraining the effectiveness and efficiency of the municipal procurement, particularly in the South African context. In this regard, Intaher \& Johanna (2012) mentioned that the competency, fairness, equity, strategies, and transparency by the personnel are the general features that need be enforced in most municipalities. Atkinson \& Sapat (2012) and Larson (2009) reported that procurement is a backbone of the municipalities in that it can open doors for the organization, such as getting new products, entering into a new market and being competitive, advancing technology, and gaining new skills. The rising need of procurement has been acknowledged by many scholars (Jovanovic \& Benkovic, 2012; Achua, 2011) and has recommended the commitment, supporting regulations, and reviewing of performance regularly to restore the image of procurements in the South African municipalities.

Moreover, the preceding authors (Intaher \& Johanna, 2012; Jovanovic \& Benkovic, 2012; Achua, 2011; Garaca, 2011; Ruankaew \& Williams, 2013) have covered the areas of operational effectiveness and efficiency and how well a municipal procurement can be implemented, but this study seeks to examine internal factors influencing the centralized procurement of stocks, in a South African municipality, with specific reference to the KwaZulu-Natal (KZN) Province. The overall aim of this research was to evaluate the internal factors influencing the centralized procurement of stocks in a South African municipality.

\section{Objectives}

The specific objectives of the research were:

- to investigate critical internal factors that influence centralized procurement process of stocks in KZN Municipality

- to assess the relationship between performance improvement of stock procurement and demographic factors

- $\quad$ to examine the relationship between understanding of ICT by staff and performance improvement on stock procurement

- $\quad$ to examine the relationship between prevention of corruption and management commitment

\section{Hypothesis Of The Study}

The above objectives were achieved by testing the following hypotheses:

- $\quad$ There is a significant relationship between performance of stock procurement and demographic factors.

- There is a significant relationship between understanding ICT and performance of stock procurement.

- There is a significant relationship between managers' commitment and prevention of corruption.

\section{LITERATURE REVIEW}

\section{Centralized Municipal Procurement}

Due to a split in the government levels and their demand for goods and services, it was not sufficient for a local community to rely on a single man. This eventually created a need for wall-to-wall service delivery to a local community which is called "centralization of procurement". This was achieved by delegating the powers of provincial government to local governments or city/municipalities. A centralized municipal procurement implies that the procurements of several contracting authorities are consolidated. This means that the needs of contracting authorities are combined in order to conduct a single municipal procurement procedure, which also leads to a decrease in costs (i.e., the purchase prices and transaction costs) and to procurement subjects that are corresponding in terms of attributes, quality and other features (Jovanovic \& Benkovic, 2012). Centralized municipal procurement services must have a clearly defined task which includes gathering and analysing data within the city/municipality 
territories, overview of procurement budgets, preparing annual procurement plans, and ensuring regular reporting of new implementations of procurement plans (Ruankaew \& Williams, 2013).

\section{ICT Adoption Into Stock Procurement}

Due to the increasing number of operating challenges across the country, regional and local governments are turning to using information communication technology (ICT) to enhance the services they provide to the community and other constituencies, but the acceptance and attitude of its users must be confirmed before its adoption because their responses are greatly important and might differ from one individual to another (Garaca, 2011). The user attitudes, in terms of new technology, can be divided into four categories - convinced user, forced user, frustrated user, and unconvinced user, but the reality is that the ICT cannot function without involving the members of staff in it (Allal-Cherif \& Babai, 2012). Therefore, it is of paramount importance for the municipalities to motivate, educate, and train, or even force, the members of staff to adapt themselves into a new technological system (Garaca, 2011). A study by Ruankaew \& Williams (2013) indicated that without measuring how the ICT contributes to optimize performances, a resistance to change by the municipal officials cannot be overcome. On the other hand, Francesco (2013) argues that even if the main goals of ICT may include rationalizing expenditure, reducing administrative confusion and costs, and fostering operational efficiency, it is also important to understand that ICT adoption does not guarantee less costs expenditure of stock procurement. Since ICT is a new language, there is still a lot to be done to improve its efficiency on procurement (Ruankaew \& Williams, 2013).

In promoting the use of ICT for economic viability, the municipal authorities have implemented accessible communication infrastructures which are to attract new business ideas and, above all, provide excellent procurement services to constituencies. The growing need of new technologies in all government sectors becomes vital in the achievement of business goals. Although this sounds quit simple, it is much difficult to carry on. Therefore, the ICT should be carried out by a practitioner with ability and enough capacity to deal with any municipal procurement processes (Allal-Cherif \& Babai, 2012). In this regard, Garaca (2011) indicated that a retiring workforce in government is a main problem that depresses performance of municipal procurement.

\section{Inbound Logistics}

A need for the inbound logistics has been viewed as necessary to enhance the diverging requirements of goods and services at lower costs. The inbound logistics costs include expenses of making requisitions, analyzing alternatives, writing purchase orders, receiving stocks, checking on orders, and maintaining records of the entire process (Jovanovic \& Benkovic, 2012). However, the inbound logistic costs should not be a great portion of total costs for stock management, although may require substantial time and procedures (Kleemann, Glas \& Essig, 2012). In the public sector, Cavinato (1992) mentioned that the inbound logistics can include nine stages - physical flow, transportation, receiving, materials handling, storage, order entry, scheduling, procurement, and control flow. In respect of a customer service, it is important to improve the inbound logistics simply because they carry the image of an organization (Akenroye, 2013). Another issue that needs serious attention from an organizational point of view is the social value of an individual. According to Mitran (2013), social values of individuals play an integral role in maintaining the inbound logistics. Social values could be defined as issues which impact on the organizational environment, including equality (i.e., gender and age), training, capacity of staffs, and motivation. Many municipalities face massive budget allocation and require considerable attention to utilize these funds in a way that will improve audit reports. Therefore, without considerable attention and devotion in the logistics, a goal, mission, and vision of the organization can be hard to achieve (Kleemann et al., 2012).

\section{Staff Competency}

Staff competency can be defined as an ability of the individual to perform a given task within a minimum period and that must be creative, innovative and vocal at a workplace (Huque \& Vyas, 2008). A South African labour legislation Act No. 12 of 2002 mentioned that a workplace is characterised as an active learning environment which seeks to provide opportunities for new entrants to the labour market to gain certain competencies (South African Department of Labour, 2013). This was confirmed by the South African Treasury Act No. 1 of 1999 which stated that a staff competency will play a vast role in terms of individual's behaviour and professional conduct 
(National Treasury Republic of South Africa, 2001). On the same note, Moreland \& Angur (2006), and a questionnaire-based study conducted by Naidoo and Wu (2011) using a mixed method approach among 570 midlevel international procurement experts from the UK, US Australia, and New Zealand, indicated that the employees' competency improved performance. On the other hand, Rehman, Khan \& Khan (2011) reported that staff competency can improve accountability.

Dragoni, In-sue, Vankatwyk, \& Tesluk (2011) mentioned that most of the critical procurement issues will require work experience and a good educational background. On the other hand, Sallop \& Kirby (2007) and Moreland \& Angur (2006) are in agreement that for the employees to be competent, they only need to deeply understand their work. The understanding of work can be attained through knowledge, training, skills and experience, and this can be achieved through commitment by the organization and its members of staff (Van Zyl, Deacon \& Rothmann, 2010). According to Aroge \& Hassan (2011), to handle the stocks of the organization requires a comprehensive knowledge as most of the workforce shortcomings, like waste, damages, and other unnatural causes on goods and services, are especially the results of employees lacking adequate skills. An observation-based study conducted by Ruankaew \& Williams (2013) from the United States indicated a significant association of staff competency with procurement. Another study by Korkmaz (2012) indicated that a strong commitment on procurement by the organization can improve performance.

\section{Planning Tools}

Planning tools are intended to integrate the resource planning activities of the organization. Some of the most common planning tools for stock procurement are Material Requirement Planning (MRP), Manufacturing Resources Planning (MRPII), and Enterprise Resource Planning (ERP). A MRP is an electronic system used to plan and control the materials and resources needed for the production of goods (Hermanovski, 2013). A MRPII system was developed in China and was first used in the United State in the 1970s. A MRPII can be defined as a manufacturing tool that integrates capabilities and capacities with the benefits of MRP (Zhao, Lai and Young, 2002). An ERP was first employed in 1990 and was designed to integrate all of the available information related to all processes in the value chain and provide it to its users at various organizational levels (Garaca, 2011).

Zhang, Prajapati \& Peden (2011) indicated that for a plan to be considered correct, it should be effective from the design stage up to its completion and implementation stages. Putting on a correct planning tool has great importance in achieving better performance (Jonsson \& Mattsson, 2008). Correspondingly, literature by Feng, Zhang, Wu \& Yu (2011) revealed that a plan tool is vitally important for the organizations that process large stocks. However, there are a lot of approaches that a government sector needs to adhere to in order to carry out a good plan. Ivanov (2010) mentioned that the government structures need to communicate effectively and arrange the resources before initiating or implementing any planning strategy. Nartisa, Putans \& Muravska (2012) indicated that there is great commitment required from the management side, but implementing a particular plan in a public sector is sometimes not taken serious. A study by Salkic (2014) indicated that the use of planning tools in a public organization enables more rational, efficient and effective management of the resources.

\section{Communication}

Procurement staffs should have regular communication and good cooperation with the Municipal Procurement Office where monthly activity reports can be submitted as a professional way of monitoring accountability of various departments within the municipality. There are five ways available for procurement staffs to communicate, including email, fax, memo, letter, notice, telephone, verbal or meeting, and via the intercom. The lines of communication are very important as they need commitment by the organization (Jovanovic and Benkovic, 2012). Poor information sharing can affect the series of inventory supply, objective links, design links, and logistics links, leading to a disapproved municipal overall control (Jayaram, Tan \& Nachiappan, 2010). Communication is the only way to convey massages and information to other people and this can be done manually or electronically, but most municipalities are in need to choose to use the electronic tools for communication (Braaf, Manias, Finch, Riley $\&$ Munro, 2012). The tools of communication are regarded as a traditional approach from which business solutions can be attained (Kishor, Sajeev \& Callender, 2006). 
Henry, Rado \& Scarlett (2012) stated that the means of communication are used by businesses to transfer data or to communicate with their customers. This might include electronic data interchange (EDI), electronic fund transfer (EFT), intranet, internet, and extranet. EDI is used for procurement to facilitate purchase orders, order status, and order follow-up. EDI was designed to assist customers to access information, dimensions, and cost about a specific product. EFT seeks to provide a way to transfer funds from one account to another through a value-added network (VAN) or the internet. Intranets used inside the organization in local area networks (LAN) or wide area networks (WAN) communicate through the internet and are secured by firewalls. Extranet allows organizations to communicate with external traders. Internet is a uniform interface that allows global communication with the use of browsers. Another significant communication tool is the ICT, as mentioned above by Garaca (2011).

\section{RESEARCH METHODOLOGY}

A literature review was used as the source of information from which to formulate the questionnaire, which consisted of closed-ended questions.

\section{Population}

A questionnaire was used to collect data from 96 staff members regarding their views on the internal factors that influence the centralized procurement of stocks. The study was confined to the procurement section of a municipal department, and this population was selected for investigation because it was relevant in the practices of a municipal procurement.

\section{Questionnaire Administration}

The standardised, self-administered questionnaire comprised a general section for biographical information. Another section dealt with the internal factors that influence centralized procurement of stocks. A mix of nominal items in the questionnaire was employed in the biographical section. Apart from the demographics, all variables were measured using a 3-point Likert scale. The researcher collected a total of 96 responses ( 82 full and 14 partially completed questionnaires). The 14 partially completed questionnaires were discarded, resulting in a final sample of 82.

\section{Data Analysis}

Using descriptive and inferential statistics, data were analysed using the Statistical Package for Social Sciences (SPSS) version 21.0. In order to test relationships, the cross-tabulations with appropriate inferential statistics (Chi-square test) were used.

\section{Reliability And Validity}

Reliability tests performed by this study were conclusive for all the ordinal questionnaire items (Cronbach's alpha $>0.5$ ). The survey's data also fully passed the validity test, as all Likert scale items split into exactly 24 components. All tests were performed with a confidence level of 0.798 , thus concluding that the reliability of the study was acceptable.

\section{RESULTS FINDINGS}

The study wished to generate opinions from the study respondents on factors influencing the centralized procurement process of stocks in a South African municipality. Using a 3-point Likert scale measurements coded as (1) Agree, (2) Neutral, and (3) Disagree, the opinions of the respondents were collected and analysed. The results are presented below. 


\section{Demographic Data}

Before any realistic measurement can be done on the effectiveness and efficiency of a municipal procurement, Mitran (2013) stressed that the factors, like gender, age, experience, and education, need to be taken into account. Therefore, it was important for this study to examine whether these factors are not problematic in a South African municipality. The results are presented in Table 1.

Table 1: Demographic Data Analysis

\begin{tabular}{|l|c|c|}
\hline & Frequency & Percent \\
\hline Gender: & & $61 \%$ \\
\hline Male & 50 & $39 \%$ \\
\hline Female & 32 & $100 \%$ \\
\hline Total & 82 & $11 \%$ \\
\hline Age: & & $21 \%$ \\
\hline 10-20yrs & 9 & $43 \%$ \\
\hline $21-30 y r s$ & 17 & $25 \%$ \\
\hline 31-40yrs & 35 & $100 \%$ \\
\hline 41yrs and above & 21 & $25 \%$ \\
\hline Total & 82 & $57 \%$ \\
\hline Qualification: & & $11 \%$ \\
\hline Secondary education & 20 & $4 \%$ \\
\hline Diploma & 47 & $2 \%$ \\
\hline Degree & 9 & $1 \%$ \\
\hline Honours & 3 & $100 \%$ \\
\hline Masters & 2 & \\
\hline Doctorate & 1 & $26 \%$ \\
\hline Total & 82 & $21 \%$ \\
\hline Experience: & & $53 \%$ \\
\hline 0-5yrs & 21 & $100 \%$ \\
\hline 6-10yrs & 17 & \\
\hline 11yrs and above & 44 & \\
\hline Total & 82 & \\
\hline
\end{tabular}

Of the 82 respondents, 50 (61 percent) were male while 32 (39 percent) were female. The results indicate the imbalance of gender. With regard to the respondents' ages, the study revealed that the majority - 35 (43 percent) - were between 31 and 40 years, 21 ( 25 percent) ranged from 41 years and above, 17 ( 21 percent) were between 21 and 30 years, and 9 (11 percent) were between 10 and 20 years. In terms of the highest qualifications of the study respondents, the survey established that the majority - 47 (57 percent) of the respondents - had a diploma, 20 (25 percent) had secondary education, 9 (11 percent) had a degree qualification, 3 (4 percent) had honours qualification, 2 (2 percent) had a master's qualification, and 1 (1 percent) had a doctoral qualification. This suggests that all study respondents had adequate educational qualifications to enable them to answer the survey instrument, but the members of staff need to be encouraged to further their studies (National Treasury Republic of South Africa, 2001). Regarding years of service, the survey established that the majority of the respondents - 44 (53 percent) - worked for 11 years and above, 21 ( 26 percent) worked for 0 to 5 years, while 17 ( 21 percent) of the respondents worked for 6 to 10 years. This points to the fact that most of the respondents were experienced since they had worked long enough to be conversant with the operations of stock procurements.

\section{Information Communication Technology (ICT)}

Garaca (2011) indicated that ICT is a challenge in most municipalities. Therefore, an analysis was done (see Table 2) to see if this is a problem facing a South African municipality. 
Table 2: The Effects Of ICT On Centralized Procurement Of Stocks

\begin{tabular}{|l|c|c|}
\hline S1.1 to S1.5 & Mean & Std. Dev \\
\hline Use of ICT on stock procurement is easily understood & 2.2805 & .93326 \\
\hline Use of ICT on stock procurement enforces transparency & 2.2683 & 1.37031 \\
\hline Use of ICT speeds up a customer service & 1.2439 & .61986 \\
\hline Use of ICT eliminate costs of stock procurement & 2.6707 & .58910 \\
\hline Use of ICT improves performance on stock procurement & 2.4268 & .87532 \\
\hline
\end{tabular}

The results in Table 2 show that statements 1.1, 1.2, and 1.5 have an average mean that is close to 2, which indicates that most of the respondents did not understand ICT and were not sure whether ICT enforces transparency or is crucial in improving performance. Therefore, the results are in agreement with the findings by Garaca (2011). Statement 1.3 has a mean that is close to 1 , which indicates that the vast majority of people agreed that the use of ICT speeds up customer service. Statement 1.4 has a mean that is close to 3, which indicates that most of the respondents were likely to disagree that the use of ICT can eliminate costs of stock procurement. In addition, statements $1.1,1.3,1.4$, and 1.5 indicate a small standard deviation with values less than 0.9 , while statement 1.2 indicates a standard deviation that is close to 1 . The values indicate that the standard deviations are close to the mean. Therefore, it can be reliably concluded that the majority of the respondents agreed with these statements.

\section{Inbound Logistics}

Due to the fact that the logistics of municipalities are allocated massive budgets, it is necessary that they pay maximum attention in utilizing funds effectively (Kleemann, Glas \& Essig, 2012). Therefore, it was appropriate for this study to investigate whether a South African municipality pays attention in the logistics of stock procurement. The results of this subject are shown in Table 3.

Table 3: The Effects Of Inbound Logistics On Centralized Procurement Of Stocks

\begin{tabular}{|l|c|c|}
\hline S2.1 to S2.5 & Mean & Std. Dev. \\
\hline A responsible official authorizes purchase & 1.1707 & .51651 \\
\hline The inbound logistics of stock procurement takes longer & 1.2073 & .58241 \\
\hline The internal logistics of stock procurement prevent corruption & 1.2683 & .64881 \\
\hline The inbound logistics pay maximum attention to those stocks whose value is highest & 1.2561 & .66316 \\
\hline The inbound logistics of stock procurement need managers' commitment & 1.1341 & .46513 \\
\hline
\end{tabular}

In Table 3, statements 2.1, 2.2, 2.3, 2.4, and 2.5 represent a mean of close to 1, which is an "Agree" perception from the respondents and indicates that most people agreed that a responsible official authorize purchase and that the inbound logistics of stock procurement takes longer, prevents corruption, pays maximum attention to those stocks whose value is highest, and that it requires management commitment. As indicated by Kleemann et al. (2012), the results quietly emphasize that a municipality must improve inbound logistics. In addition, statements 2.1, $2.2,2.3,2.4$, and 2.5 indicate a small standard deviation with values less than 0.9 . The values indicate that the standard deviation is close to the mean. Therefore, it can be reliably concluded that the majority of the respondents agreed with these statements.

\section{Staff Competency}

In order to perform the duties of public procurement, an individual is required to have relevant skills and comprehensive knowledge in the field (Aroge \& Hassan, 2011). This subject led to this study to investigate whether the members of staff in a South African municipality are faced with this problem. Table 4 presents the results.

Table 4: The Effects Of Staff Competency On Centralized Procurement Of Stocks

\begin{tabular}{|l|c|c|}
\hline S3.1 to S3.4 & Mean & Std. Dev \\
\hline Stock procurement requires a university qualification & 1.3293 & .68592 \\
\hline Stock procurement require a college qualification & 2.2439 & .82494 \\
\hline People involved with stock procurement need to be well trained & 1.1463 & .47459 \\
\hline Stock procurement require an ethical behaviour & 1.0854 & .35836 \\
\hline
\end{tabular}


Table 4 illustrates that statements 3.1,3.3, and 3.4 have a mean of 1.3293,1.1463, and 1.0854, respectively, which is close to 1 . A mean of 1 represents an "Agree" perception of participants, which indicates that most of the respondents agreed that a stock procurement requires a university qualification, people involved with stock procurement need to be well trained, and that a stock procurement requires an ethical behaviour of individuals. Statement 3.2 has a mean that is close to 2 which represents a "Neutral" perception from the participants. This indicates that most of the respondents were not sure whether a college qualification is appropriate for stock procurement carrier. Therefore, the results lead to a common direction with Aroge \& Hassan (2011) in that the members of the staff need to be educated and well trained for a stock procurement. However, statements 3.1, 3.2, 3.3, and 3.4 indicate a small standard deviation with values less than 0.9 , which indicates that the standard deviation is close to the mean. Therefore, it can be reliably concluded that the majority of the respondents agreed with the statements.

\section{Planning}

Gupta, Gopalakrishnan, Chaudhari \& Jalali (2011) indicated that planning can play a huge role in achieving a great performance in the procurement practices. Therefore, in this study, it was necessary to examine if a South African municipality is experiencing any problems on planning. The results are shown in Table 5.

Table 5: The Effects Of Planning On Centralized Procurement Of Stocks

\begin{tabular}{|l|c|c|}
\hline S4.1 to S4.5 & Mean & Std. Dev \\
\hline It is important to make plans for stock procurement & 1.1707 & .53989 \\
\hline Electronic tools are used to facilitate planning & 1.0366 & .24571 \\
\hline Use of electronic tools can help to manage the resource planning activities & 1.6098 & .89933 \\
\hline $\begin{array}{l}\text { All the members of staff who are involved with stock procurement are in charged with } \\
\text { planning }\end{array}$ & 2.1951 & .97422 \\
\hline Planning tools are understandable & 2.2561 & .96623 \\
\hline
\end{tabular}

Statements 4.1 and 4.2 illustrated in Table 5 indicate a mean that is close to 1, which represents an "Agree" perception from the participants. This indicates that most of the respondents agreed that it is important to plan for a stock procurement and that a South African municipality use the electronic tools to facilitate planning. Statements $4.3,4.4$, and 4.5 have a mean close to 2 . This indicates that the majority of the respondents were not sure whether the use of electronic tools can help manage the resource planning activities, whether the members of staff involved with stock procurement are in charged with planning, and whether they understand the tools of planning applied by an organization. Therefore, the results are in line with Gupta, Gopalakrishnan, Chaudhari \& Jalali (2011) in that planning is very important for a stock procurement. In addition, statements $4.3,4.4$, and 4.5 have standard deviation values around 1 , while statements 4.1 and 4.2 indicate a small standard deviation with values less than 0.9. Since the standard deviation values are clustered closely around the mean, it gives a reliable reflection that most of the respondents agreed with the statements.

\section{Communication}

Braaf et al. (2012) suggested that most municipalities are in need of choosing to use electronic tools for successful communications of procurement. Therefore, as i illustrated in Table 6, it was very important for this study to see if communication is a challenge in a South African municipality.

Table 6: The Effects Of Communication On Centralized Procurement Of Stocks

\begin{tabular}{|l|c|c|}
\hline S5.1 to S5.5 & Mean & Std. Dev \\
\hline Stock procurement needs a regular communication & 1.0244 & .22086 \\
\hline Management support improves communication & 1.2073 & .56082 \\
\hline Use of electronic tools improves communication & 1.9146 & .99630 \\
\hline Use of electronic tools is understandable & 1.5122 & .86415 \\
\hline Use of electronic tools to communicate improves performance & 1.4634 & .80423 \\
\hline
\end{tabular}

Table 6 indicates that statements 5.1 and 5.2 have a mean close to 1, which is an "Agree" perception from the respondents and indicates that most of the respondents agreed that stock procurement needs a regular 
communication and that management support improves communication. Statements 5.3, 5.4, and 5.5 have a mean close to 2, which is a "Neutral" perception from the respondents and indicates that most of the respondents were not sure whether the use of electronic tools improves communication and performance and that they do not understand the electronic tools used by an organization. In addition, statements 5.3 and 5.4 have standard deviation values around 1, while statements 5.1, 5.2 and 5.5 indicate a small standard deviation with values less than 0.9. Since the standard deviation values are clustered closely about the mean, it gives a reliable reflection that most of the respondents agreed with the statements.

\section{Hypothesis Tests: P-Values And Statistical Significance}

The researcher conducted Chi-square tests to assess significance of relationships among the research variables. The researcher applied the statistical package for social sciences (SPSS) to code, enter and compute the measurements of the study. All significant relationships are indicated by a* or **. At 5\% level of significance and $95 \%$ level of confidence, $\mathrm{a} *$ is significant at a level of 0.05 or below, whereas a ** is significant at a level of 0.01 or below. This study developed three hypothesises: (1) that there is a statistically significant relationship between performance of stock procurement and demographic factors, (2) that there is a statistically significant relationship between understanding ICT and performance of stock procurement, and (3) that there is a statistically significant relationship between managers' commitment and prevention of corruption. Therefore, these results are presented in Table 7.

Table 7: Hypothesis Tests

\begin{tabular}{|c|c|c|c|c|c|c|}
\hline \\
\hline & & S1.1 & S1.2 & S1.3 & S1.4 & S1.5 \\
\hline \multirow[t]{3}{*}{ Gender } & Pearson Correlation & -.194 & .170 & .194 & $-.242^{*}$ & .153 \\
\hline & Sig. (2-tailed) & .080 & .126 & .081 & .029 & .169 \\
\hline & $\mathrm{N}$ & 82 & 82 & 82 & 82 & 82 \\
\hline \multirow[t]{3}{*}{ Qualification } & Pearson Correlation & -.013 & $.493^{* * *}$ & -.073 & .008 & $.233 *$ \\
\hline & Sig. (2-tailed) & .911 & .000 & .513 & .941 & .035 \\
\hline & $\mathrm{N}$ & 82 & 82 & 82 & 82 & 82 \\
\hline \multirow{3}{*}{ Experience } & Pearson Correlation & $-.373^{* *}$ & .079 & $-.257^{*}$ & $-.256^{*}$ & $.501 * *$ \\
\hline & Sig. (2-tailed) & .001 & .478 & .020 & .020 & .000 \\
\hline & $\mathrm{N}$ & 82 & 82 & 82 & 82 & 82 \\
\hline \multirow[t]{3}{*}{ Age } & Pearson Correlation & $-.271^{*}$ & -.097 & -.147 & $-.367^{* * 1}$ & $.630 * *$ \\
\hline & Sig. (2-tailed) & .014 & .385 & .187 & .001 & .000 \\
\hline & $\mathrm{N}$ & 82 & 82 & 82 & 82 & 82 \\
\hline \multirow[t]{4}{*}{ S1.1 } & Pearson Correlation & 1 & $.336^{* * *}$ & -.013 & -.167 & $-.239^{*}$ \\
\hline & Sig. (2-tailed) & & .002 & .908 & .134 & .031 \\
\hline & $\mathrm{N}$ & 82 & 82 & 82 & 82 & 82 \\
\hline & & $\mathrm{S} 2.1$ & S2.2 & $\mathrm{S} 2.3$ & S2.4 & S2.5 \\
\hline \multirow[t]{3}{*}{ S2.3 } & Pearson Correlation & -.138 & .178 & 1 & .211 & $.370 * *$ \\
\hline & Sig. (2-tailed) & .215 & .110 & & .057 & .001 \\
\hline & $\mathrm{N}$ & 82 & 82 & 82 & 82 & 82 \\
\hline
\end{tabular}

* Correlation is significant at the 0.05 level (2-tailed).

** Correlation is significant at the 0.01 level (2-tailed).

Table 7 shows that, in terms of the demographic factors, gender and S1.5 (Use of ICT improves performance on stock procurement) had a significant relationship of $\mathrm{p}=.169$, qualification and $\mathrm{S} 1.5$ showed a significant relationship of $\mathrm{p}=.035$, while experience and $\mathrm{S} 1.5$ showed a significant relationship of $\mathrm{p}=.000$. In terms of S1.1 (Use of ICT on stock procurement is easily understood) and S1.5, the results showed a significant relationship of $\mathrm{p}=.031$, while S2.3 (inbound logistics of stock procurement prevent corruption) and S1.5 showed a significant relationship of $p=.013$. Basically, the results showed a null hypothesis of $p=.169$ between performance improvement on stock procurement and gender. On the other hand, performance improvement on stock procurement showed significant relationships with qualification, experience, and age of $\mathrm{p}=.035, \mathrm{p}=.000$, and $\mathrm{p}=.000$, respectively. The study also proved a significant relationship of $\mathrm{p}=.031$ between understanding ICT and performance improvement and that prevention of corruption is significantly related with management commitment at $\mathrm{p}=.001$. 


\section{Limitations}

This study was confined to only one South Africa municipality, with specific reference to the KwaZuluNatal (KZN) Province. Therefore, the results of the study cannot be generalized to all South Africa municipalities.

\section{CONCLUSION AND RECOMMENDATIONS}

Research was conducted to examine the internal factors influencing centralized procurement process of stocks in a South African municipality, with specific reference to the KwaZulu-Natal (KZN) Province. The role played by centralized procurement of stocks in enhancing the success of local government performance, particularly in KZN, is generally well recognized today. Nevertheless, simplification of procurement procedures should be one of the key priorities, as this issue has recently resulted in the increase of complaints. This has created an atmosphere of cautions, mainly among the local municipalities, government, and scholars, since, in most instances, the government does not deal directly with the society but through local municipalities. In order to avoid deficiencies, which can lead to failure of centralized procurement of stocks, a clear line of responsibility should be demarcated, e.g., in the form of a linear responsibility chart. Tools, such as a work breakdown structure, should be used to break down activities assignable to specific individuals. The current situation reflects a dominance of males in the procurement of stocks. Furthermore, a significant proportion of members of staff are close to 50 years of age, making it necessary for the appropriate measures to be taken to ensure capacity in the industry in the future. Based on the results, the study recommends that a supporting internal control should be established to ensure that the centralization of stocks by procurement is executed by individuals with a clear understanding of inbound logistics, clear communication, commitment, and comprehensive planning. Since the findings of this study are based on 82 members of staff from one South African municipality, it is recommended that a larger sample size may be used in future studies in order to improve accuracy of the results.

\section{AUTHORS INFORMATION}

Mr Zwelihle Wiseman NZUZA is pursuing his Master's degree in Cost and Management Accounting and is registered under the Faculty of Accounting and Informatics at the Durban University of Technology, South Africa. E-mail: zwnzuza@gmail.com.

Dr Lawrence Mpele LEKHANYA is a Postdoctoral Fellow in the Department of Public Management and Economics at the Durban University of Technology, South Africa. He obtained his Masters and Doctor of Technology: Marketing degrees from Durban University of Technology. He has published in refereed journals and supervises Masters and Doctoral students in a number of universities in South Africa. He is currently working towards publishing a prescribed textbook on Entrepreneurial Marketing. Email: lekhanyam@yahoo.com or lawrencel@dut.ac.za.

\section{REFERENCES}

1. Achua, J. K. (2011). Anti-corruption in public procurement in Nigeria: Challenges and competency strategies: Journal of public procurement, 11(3): 323.

2. Akenroye, T. O. (2013). An appraisal of the use of social criteria in public procurement in Nigeria: Journal of public procurement, 13(3): 365.

3. Allal-Cherif, O. \& Babai, M. Z. (2012). Do electronic marketplaces improve procurement performance?: Supply chain forum: International journal, 13(3): 40.

4. Aroge, S. T. \& Hassan, M. A. (2011). The responsibility of human resource management and development professionals in the development of low skilled workers in the Nigeria public sector: International journal of business \& management, 6(11): 229.

5. Atkinson, C. L. \& Sapat, A. K. (2012). After Katrina: comparisons of post disaster public procurement approaches and outcomes in the New Orleans area: Journal of public procurement, 12(3): 360-363.

6. Braaf, S., Manias, E., Finch, S., Riley, R., \& Munro, F. (2012). Health care service provider perceptions of organizational communication across the perioperative pathway: A questionnaire survey: Journal of clinical nursing, 22(1/2): 3 . 
7. Cavinato, J. L. (1992). Evolving procurement organizations: logistics implications: Journal of business logistics, 13(1): 30.

8. Dragoni, L., In-sue, O., Vankatwyk, P., \& Tesluk, P. E. (2011). Developing executive leaders: the relative contribution of cognitive ability, personality, and the accumulation of work experience in predicting strategic thinking competency: Personnel psychology, 64(4): 830-831.

9. $\quad$ Feng, P., Zhang, J., Wu, Z., \& Yu, D. (2011). An improved production planning method for process industries: International journal of production research, 49(14): 4223.

10. Francesco, G. (2013). A model to measure e-procurement impacts on organizational performance: Journal of public procurement, 13(2): 216-217.

11. Garaca, Z. (2011). Factors related to the intended use of ERP systems: Management: Journal of Contemporary Management Issues, 16(2): 23-24.

12. Gupta, D. P., Gopalakrishnan, B., Chaudhari, S. A., \& Jalali, S. (2011).Development of an integrated model for process planning and parameter selection for machining processes: International journal of production research, 49(21): 6301.

13. Henry, Q., Rado, G., \& Scarlett, S. (2012). Critical Factors Affecting Supply Chain Management: A Case Study in the US Pallet Industry, Pathways to Supply Chain Excellence, Dr. Ales Groznik (Ed.), ISBN: 978 953-51-0367-7, InTech, Available WWW: http://www.intechopen.com/books/pathways tosupply(Accessed 05 May 2014).

14. Hermanovski, L. (2013). A study regarding the implementation of MRP systems in Romanian manufacturing companies: Review of management \& economic engineering, 12(1): 73.

15. Huque, A. S. \& Vyas, L. (2008). Expectations and performance: assessment of public service training in Hong Kong: International journal of human resource management, 19(1): 188.

16. Intaher M. A. \& Johanna, A. B. (2012). Procurement challenges in the South African public sector: Journal of transport and supply chain management, 6(1): 242-255.

17. Ivanov, D. (2010). An adaptive framework for aligning (re)planning decisions on supply chain strategy, design, tactics, and operations: International journal of production research, 48(13): 4010.

18. Jayaram, J., Tan, K., \& Nachiappan, S. P. (2010). Examining the interrelationships between supply chain integration scope and supply chain management efforts: International journal of production research, 48(22): 6840 .

19. Jonsson, P. \& Mattsson, S. A. (2008). Inventory management practices and their implications on perceived planning performance: International journal of production research, 46(7): 1788-1789.

20. Jovanovic, P. \& Benkovic, S. (2012). Improvements in organizing public procurement at the local self government level in Serbia: Management (1820-0222), 64(1): 27-64.

21. Kishor, V., Sajeev, A. S. M., \& Callender, G. (2006). Critical factors that influence e-procurement implementation success in the public sector: Journal of public procurement, 6(1): 72.

22. Kleemann, F. C., Glas, A., \& Essig, M. (2012). Public procurement through performance-based logistics: conceptual underpinnings and empirical insights: Journal of public procurement, 12(2): 152-161. Korkmaz, O. (2012). Differences in employees' perception of employee empowerment practices: European journal of social science, $34(1): 43$.

23. Larson, P. D. (2009). Public vs. Private sector perspectives on supply chain management: Journal of public procurement, 9(2): 222.

24. Mitran, D. (2013). Improving access of SMEs to the public procurement markets: Internal auditing \& risk management, 8(2): 259.

25. Moreland, K. A. \& Angur, M. (2006). The Importance of work experience to accountants' professional development: Journal of American academy of business, Cambridge, 9(2): 9.

26. Naidoo, V. \& Wu, T. (2011). Marketing strategy implementation in higher education: A mixed approach for model development and testing: Journal of marketing management, 27(11): 1125.

27. Nartisa, I., Putans, R., \& Muravska, T. (2012). Strategic planning and management in public and private sector organizations in Europe: comparative analysis and opportunities for improvement: European integration studies, 6(5): 240.

28. National treasury republic of South Africa. (2001). Available: http://www.treasury.gov.za/legislation/pfma/regulations/gazette_22141.pdf (Accessed 24 January 2014).

29. Policy strategy to guide uniformity in procurement reform processes in government. (2003). Available WWW: https://www.environment.gov.za/.../procurement_process_uniformstrateg (Accessed 05 May 
2014).

30. Ruankaew, T. \& Williams, P. (2013). The impact of inventory inaccuracy in the food manufacturing industry: A case study: Business management dynamics, 2(10): 27.

31. Rehman, A., Khan, A. M., \& Khan, R. A. (2011). Measuring training effectiveness: a case study of public sector project management in Pakistan: Journal of diversity management, 6(1): 40-41.

32. Salkic, I. (2014). Impact of strategic planning on management of public organizations in Bosnia and Herzegovina: Interdisciplinary description of complex systems, 12(1): 63.

33. Sallop, L. J. \& Kirby, S. L. (2007). The role of gender and work experience on career and work force diversity expectations: Journal of behavioural \& applied management, 8(2): 127.

34. South African department of labour policy. (2013). Available WWW: www.labour.gov.za/DOL/documents (Accessed 15 March 2013).

35. Van Zyl, L. E., Deacon, E., \& Rothmann, S. (2010). Towards happiness: experiences of work-role fit, meaningfulness and work engagement of industrial/organisational psychologists in South Africa: SAJIP: South African journal of industrial psychology, 36(1): 2.

36. Watermeyer, R. B. (2011). Public procurement regulation in Africa conference: Regulating public procurement in Southern Africa through international and national standards. Available WWW: www.ssinc.co.za/Files/Doc/RBWPapers/T3-18.pdf (Accessed 25 January 2014).

37. Zhang, X., Prajapati, M., \& Peden, E. (2011). A stochastic production planning model under uncertain seasonal demand and market growth: International journal of production research, 49(7): 1956-1961.

38. Zhao, X., Lai, F., \& Young, S. (2002). A study of manufacturing resources planning (MRPII) implementation in china: International journal of production research, 40(14): 3461. 